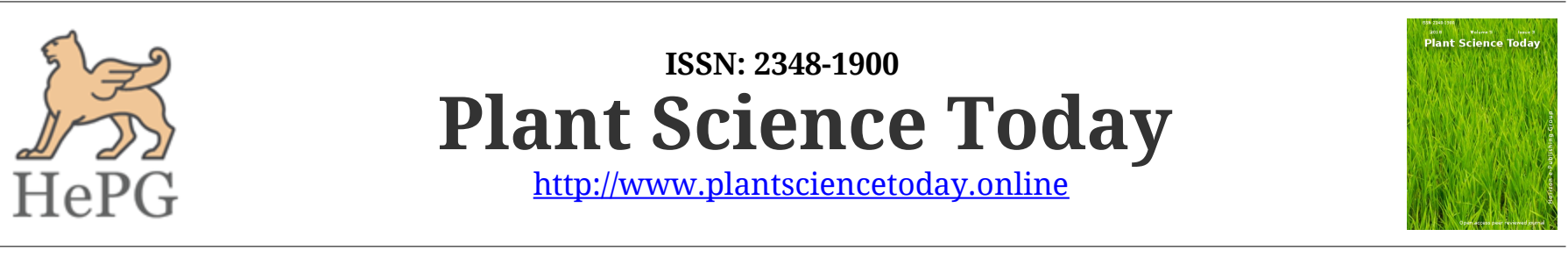

Research Article

\title{
Optimization of culture conditions for extracellular fungal lipase production by submerged fermentation process
}

\author{
${ }^{1}$ Shreya, ${ }^{\text {*1}}$ Arun Kumar Sharma, ${ }^{2}$ Vinay Sharma, ${ }^{3}$ Jyoti Saxena \\ ${ }^{1}$ Department of Bioscience and Biotechnology, Banasthali Vidyapith, Rajasthan, India \\ ${ }^{2}$ Amity University, Rajasthan, India \\ ${ }^{3}$ Department of Biochemical Engineering, Bipin Tripathi Kumaon Institute of Technology, Dwarahat, Uttrakhand, India
}

\section{Article history}

Received: 17 May 2018

Accepted: 30 August 2018

Published: 08 September 2018

\section{Editor}

Dr. Dan Cristian Vodnar, University of Agricultural Sciences and Veterinary Medicine, Romania

\section{Publisher}

Horizon e-Publishing Group

\author{
*Correspondence \\ Arun Kumar Sharma \\ $\square$ arun.k.sharma84@gmail.com
}

\begin{abstract}
The present study aimed to optimize culture conditions for optimal growth and production of extracellular lipase. Lipolytic fungal strain named as S3St2 previously isolated from a petrol pump soil sample of Newai Town was used for optimization study. Among the tested carbohydrate carbon sources, polysaccharide-starch exhibited maximum lipase production $(21.25 \pm 0.70 \mathrm{IU} / \mathrm{ml} / \mathrm{min})$ with highest specific activity $(1.47 \pm 0.06 \mathrm{U} / \mathrm{mg})$. Lipase activity and specific activity were higher with mustard oil 1 $\%(\mathrm{v} / \mathrm{v})$ among all lipidic carbon sources. Among inorganic nitrogen source, potassium nitrate was found best inducer of lipase activity, malt extract supported the fungus growth (dry weight of cell pellets was $0.467 \mathrm{~g}$ ) and exhibited maximum lipase activity among all organic nitrogen sources. Lipase activity was optimum at pH 8.0, indicates alkalophillic nature of production media supports the growth of fungus. Higher lipase activity $(27.92 \pm 0.87 \mathrm{IU} / \mathrm{ml} / \mathrm{min})$ was detected at $28^{\circ} \mathrm{C}$. The incubation time of 5 days was found optimum for maximum lipase production $(31.51 \pm 0.21 \mathrm{IU} / \mathrm{ml} / \mathrm{min})$.
\end{abstract}

Keywords

Carbon sources; fungal isolate; lipases; optimization

\section{Citation}

Shreya, Sharma AK, Sharma V, Saxena J. Optimization of culture conditions for extracellular fungal lipase production by submerged fermentation process. Plant Science Today 2018;5(3):135-141. https://dx.doi.org/10.14719/pst.2018.5.3.399

Copyright: (C) Shreya et al (2018). This is an open-access article distributed under the terms of the Creative Commons Attribution License, which permits unrestricted use, distribution, and reproduction in any medium, provided the original author and source are credited (https://creativecommons.org/licenses/by/4.0/).

\section{Introduction}

Lipases (EC 3.1.1.3) are triacylglycerolester hydrolases that cleave the triaclyglycerol into glycerol and fatty acids. They frequently exhibit other properties such as amidase, phospholipase, cutinase, cholesterol esterase and isophospholipase (1).
Lipases are mainly found in fungi, yeasts, bacteria, plants and animals $(2,3,4)$. At present microbial lipases plays a vital role and potential applications in industry, mostly in the dairy, detergents, oils, fats and pharmaceutical industries due to their potential towards extremes of $\mathrm{pH}$, organic solvents, temperature, chemoselectivity and regioselectivity $(5,6)$. 
For last few decades, qualitative and quantitative improvement demands enhanced due to increase in application of lipases in different fields. The lipase produced by wild strains are less in quantity therefore, medium optimization and strain improvement required for overproduction of lipase than produced by the wild strains $(7,8,9)$. Lipases posses specificity to a reaction and makes postreaction simpler.

Lipases activity is entirely associated with oil bodies confirmed through histochemical study. Presently, microbial lipases are mainly emphasized on conversion of processing industry wastes $(10,11)$.

In culture media lipases are mostly secreted out but intracellular lipases and membrane bound lipases have been also reported. Beginning of lipase production is an organism precise but released during stationary phase or late logarithmic phase $(12,13,14)$.

Type and concentration of carbohydrate and lipidic carbon sources, inorganic nitrogen and organic nitrogen sources, the $\mathrm{pH}$ of production media, temperature and incubation time influences lipase production by microbial strains (15). Most commonly used lipidic substrate for increased lipase production is olive oil (16).

\section{Materials and Method}

All glassware's and chemicals were used from SRL Pvt. Ltd., India, Merck Specialities Pvt. Ltd., India, Sigma Aldrich Chemicals Pvt. Ltd., India, Riviera Glass Private Limited, Borosil Glass Works Ltd, India and HiMedia Laboratories Ltd., India.

\section{Isolation and maintenance of lipolytic fungi}

The lipolytic fungal strain named as S3St2 (Fig. 1) was obtained from the Department of Bioscience and Biotechnology, Banasthali Vidyapith which was previously isolated from the petrol pump soil sample of Newai Town (Raj) and screened for lipolytic activity on tributyrin agar (TBA) plates. It was subcultured \& maintained on PDA slants and used for culture conditions optimization under submerged fermentation (SmF) (17).

\section{Optimization of culture condition}

Culture conditions (carbohydrate carbon sources, lipidic carbon sources, organic and inorganic nitrogen sources, $\mathrm{pH}$, temperature and incubation time) were optimized for lipase production from fungal isolate (S3St2). Composition of fermentation broth $(\mathrm{g} / 100 \mathrm{ml})$ used for optimization was $0.1 \mathrm{~g}$ of $\left(\mathrm{NH}_{4}\right)_{2} \mathrm{SO}_{4}, 0.1 \mathrm{~g}$ of $\mathrm{MgSO}_{4} .7 \mathrm{H}_{2} \mathrm{O}, 0.1 \mathrm{~g}$ of $\mathrm{KH}_{2} \mathrm{PO}_{4}, 4 \mathrm{~g}$ of peptone, $0.5 \mathrm{~g}$ of Sucrose, $1 \mathrm{ml}$ of olive oil with $\mathrm{pH}$ $6.5 \pm 0.2$ (18).

\section{Optimization of carbohydrate carbon source for lipase production}

The effect of different carbon source on lipase production was assessed by culturing the fungal isolate (S3St2) in fermentation broth. Original carbohydrate source (sucrose) was replaced by different carbohydrate sources (glucose, maltose, fructose, lactose and starch). Rest composition of production media was retained same. One flask was kept as control containing sucrose as original carbon source (19). One $\mathrm{ml}$ of spore suspension was inoculated in each flask containing production media with different carbon source. Flasks were incubated at $28^{\circ} \mathrm{C}$ at $120 \mathrm{rpm}$ for 5 days in shaking incubator.

\section{Optimization of lipidic carbon source for lipase production}

Optimized carbohydrate carbon source from previous experiment was used for preparation of culture medium for further optimization study. Original lipidic source (olive oil $1 \% \mathrm{v} / \mathrm{v}$ ) of production media was replaced by other lipidic sources such as amla oil, mustard oil, coconut oil and almond oil at the same concentration. One flask was kept as control containing olive oil as original carbon source (20). Lipase activity and protein contents $(21,22)$ were determined after 5 days of incubation (23). Flaks were inoculated with one $\mathrm{ml}$ of spore suspension from slant culture. Lipase activity and protein content were determined after 5 days of incubation. One unit of lipase was defined as amount $(\mu \mathrm{M})$ of product ( $p$-nitrophenol) released by one $\mathrm{ml}$ of crude lipase in $1 \mathrm{~min}$ of reaction time at standard assay conditions.

\section{Optimization of inorganic nitrogen source for} lipase production

Optimized carbohydrate and lipidic carbon sources from previous experiments were used for further optimization of culture conditions. Original inorganic $\left(\mathrm{NH}_{4}\right)_{2} \mathrm{SO}_{4}$ nitrogen source $(0.1 \% \mathrm{w} / \mathrm{v})$ of production media were replaced by different inorganic nitrogen sources such as $\mathrm{KNO}_{3},\left(\mathrm{NH}_{4}\right) \mathrm{NO}_{3}$ and $\mathrm{NaNO}_{3}$. One flask was kept as control containing $\left(\mathrm{NH}_{4}\right)_{2} \mathrm{SO}_{4}$ as original carbon source (24). Flasks were inoculated and activity was determined.

Optimization of organic nitrogen source for lipase production

Previously optimized carbon and inorganic nitrogen sources were used for further optimization study. Original organic nitrogen source i.e. peptone $(4 \%$ $\mathrm{w} / \mathrm{v}$ ) of production media was replaced by different organic nitrogen sources such as beef extract, malt extract, yeast extract, urea and tryptone at a concentration of $4 \% \mathrm{w} / \mathrm{v}$. Flaks were inoculated with $1 \mathrm{ml}$ of spore suspension from 8 days old slant culture. Lipase activity and protein content were determined after 5 days of incubation (23).

\section{Optimization of $\mathrm{pH}$ for lipase production}

Previously optimized culture conditions were used to further study the effect of different $\mathrm{pH}$ for lipase production in production media. The $\mathrm{pH}$ of production media was changed from 7 to $4,5,6,8,9$, 10, 11 and lipase production was estimated at fifth day of incubation (20). 
Table 1. Influence of different sources on specific activity and lipase production by fungal isolate (S3St2)

\begin{tabular}{|c|c|c|c|}
\hline Different sources & $\begin{array}{c}\text { Lipase activity } \\
\text { (IU/ml/min) }\end{array}$ & $\begin{array}{c}\text { Specific activity } \\
\text { (U/mg) }\end{array}$ & $\begin{array}{c}\text { Dry weight of fungal cell } \\
\text { pellets (g) }\end{array}$ \\
\hline \multicolumn{4}{|l|}{ Day 4 (Carbon Source) } \\
\hline Glucose & $5.30 \pm 0.08$ & $0.35 \pm 0.02$ & 0.291 \\
\hline Starch & $21.25 \pm 0.70$ & $1.47 \pm 0.06$ & 0.232 \\
\hline Fructose & $8.88 \pm 0.57$ & $0.58 \pm 0.04$ & 0.494 \\
\hline Maltose & $5.65 \pm 0.46$ & $0.40 \pm 0.04$ & 0.672 \\
\hline Lactose & $9.40 \pm 0.86$ & $0.71 \pm 0.08$ & 0.368 \\
\hline Sucrose & $7.40 \pm 0.79$ & $0.52 \pm 0.06$ & 0.317 \\
\hline \multicolumn{4}{|l|}{ Day 4 (Lipidic Source) } \\
\hline Amla oil & $0.88 \pm 0.13$ & $0.05 \pm 0.08$ & - \\
\hline Mustard oil & $13.93 \pm 0.38$ & $0.85 \pm 0.02$ & 0.298 \\
\hline Almond oil & $0.90 \pm 0.13$ & $0.05 \pm 0.07$ & - \\
\hline Coconut oil & $1.41 \pm 0.60$ & $0.08 \pm 0.03$ & 0.145 \\
\hline Olive oil & $0.43 \pm 0.09$ & $0.02 \pm 0.05$ & 0.102 \\
\hline \multicolumn{4}{|l|}{ Day 6 (Inorganic Source) } \\
\hline $\mathrm{KNO}_{3}$ & $14.04 \pm 0.87$ & $0.95 \pm 0.10$ & 0.366 \\
\hline$\left(\mathrm{NH}_{4}\right) \mathrm{NO}_{3}$ & $10.22 \pm 0.75$ & $0.58 \pm 0.04$ & 0.308 \\
\hline$\left(\mathrm{NH}_{4}\right)_{2} \mathrm{SO}_{4}$ & $1.58 \pm 0.28$ & $0.09 \pm 0.00$ & 0.398 \\
\hline $\mathrm{NaNO}_{3}$ & $9.18 \pm 0.74$ & $0.56 \pm 0.07$ & 0.578 \\
\hline \multicolumn{4}{|l|}{ Day 4 (Organic Source) } \\
\hline Beef extract & $0.64 \pm 0.29$ & $1.15 \pm 0.02$ & - \\
\hline Malt extract & $15.29 \pm 0.96$ & $1.19 \pm 0.02$ & 0.467 \\
\hline Tryptone & $10.85 \pm 0.32$ & $0.78 \pm 0.03$ & 0.234 \\
\hline Yeast extract & $8.29 \pm 0.45$ & $0.77 \pm 0.08$ & 0.287 \\
\hline Peptone & $0.64 \pm 0.22$ & $0.06 \pm 0.02$ & 0.186 \\
\hline Urea & $0.72 \pm 0.38$ & $0.06 \pm 0.03$ & - \\
\hline \multicolumn{4}{|l|}{ Day 5 (pH) } \\
\hline 4 & $2.95 \pm 0.42$ & $0.70 \pm 0.09$ & 0.193 \\
\hline 5 & $3.56 \pm 0.57$ & $0.99 \pm 0.20$ & 0.563 \\
\hline 6 & $2.55 \pm 0.89$ & $0.60 \pm 0.26$ & 0.983 \\
\hline 7 & $6.95 \pm 0.22$ & $2.06 \pm 0.09$ & 0.678 \\
\hline 8 & $7.74 \pm 0.42$ & $1.90 \pm 0.27$ & 0.908 \\
\hline 9 & $5.11 \pm 0.36$ & $0.87 \pm 0.08$ & 0.797 \\
\hline 10 & $3.40 \pm 0.16$ & $0.70 \pm 0.10$ & 1.589 \\
\hline 11 & $1.24 \pm 0.16$ & $0.10 \pm 0.01$ & 0.187 \\
\hline \multicolumn{4}{|l|}{ Day 5 (Temperature) } \\
\hline $28^{\circ} \mathrm{C}$ & $27.92 \pm 0.87$ & $2.65 \pm 0.06$ & 0.984 \\
\hline $37^{\circ} \mathrm{C}$ & $8.82 \pm 0.27$ & $1.83 \pm 0.11$ & 0.543 \\
\hline \multicolumn{4}{|l|}{ Day 2-8 (Incubation Time) } \\
\hline Day 2 & $3.61 \pm 0.57$ & $1.88 \pm 0.35$ & 0.194 \\
\hline Day 3 & $11.03 \pm 0.89$ & $3.79 \pm 1.22$ & 0.246 \\
\hline Day 4 & $14.07 \pm 0.59$ & $2.16 \pm 0.34$ & 0.482 \\
\hline Day 5 & $31.51 \pm 0.21$ & $3.91 \pm 0.03$ & 0.694 \\
\hline Day 6 & $15.87 \pm 0.22$ & $3.20 \pm 0.61$ & 0.367 \\
\hline Day 7 & $5.71 \pm 0.63$ & $1.53 \pm 0.23$ & 0.548 \\
\hline Day 8 & $5.82 \pm .062$ & $1.59 \pm 0.17$ & 0.652 \\
\hline
\end{tabular}

\section{Optimization of temperature for lipase production}

Previously optimized culture conditions (carbohydrate carbon source, lipidic carbon source, inorganic nitrogen source, organic nitrogen source and $\mathrm{pH}$ ) were used for media preparation to optimize the suitable temperature for growth. Fermentation broth was prepared (starch $0.5 \% \mathrm{w} / \mathrm{v}$, mustard oil $1 \% \mathrm{v} / \mathrm{v}, \mathrm{KNO}_{3} 0.1 \% \mathrm{w} /$ $\mathrm{v}$, malt extract $4 \% \mathrm{w} / \mathrm{v}, \mathrm{pH} 8$ ) and inoculated with 1 $\mathrm{ml}$ of spore suspension. Flasks were incubated at $28^{\circ} \mathrm{C}$ and $37^{\circ} \mathrm{C}$ followed by determination of lipase activity (25).

\section{Optimization of incubation period for lipase production}

Previously optimized culture conditions were used for preparation of culture media. $1 \mathrm{ml}$ of spore suspension was inoculated in production media and incubated for 7 days at optimized temperature $\left(28^{\circ} \mathrm{C}\right)$. Lipase activity and protein content were determined at following days of incubation 2, 3, 4, 5, 6, 7 and 8 (26). 


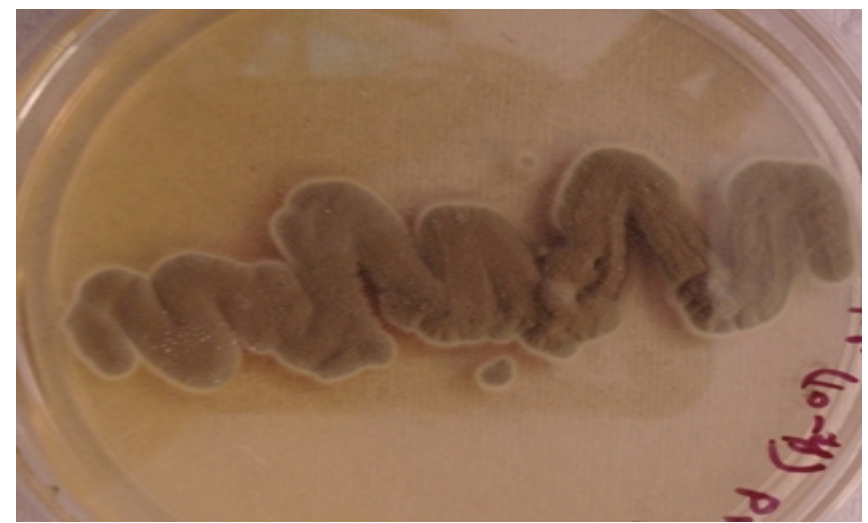

Fig 1. PDA Petri plate culture of fungal isolate S3St2

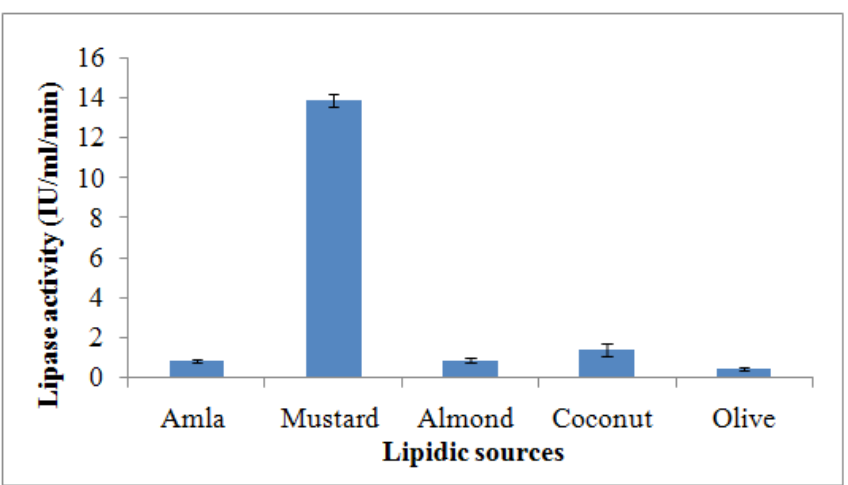

Fig 3. Effect of different lipidic sources on lipase production by S3St2

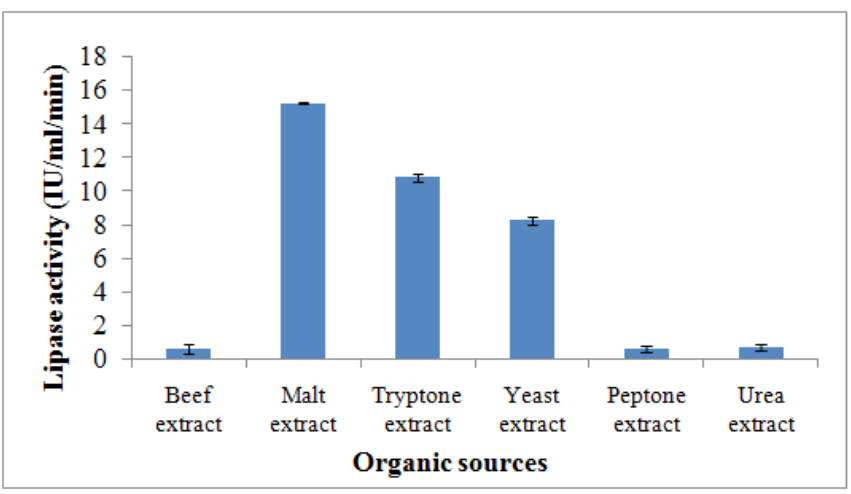

Fig 5. Effect of different organic nitrogen sources on lipase production by S3St2

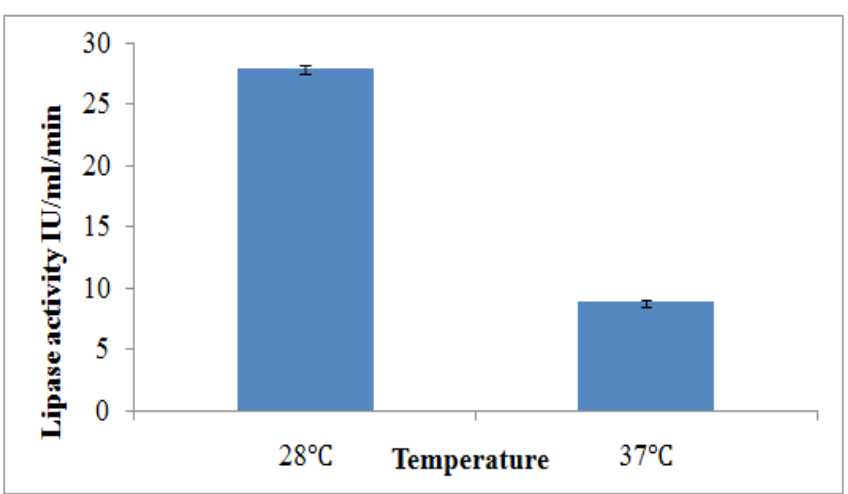

Fig 7. Effect of different temperature on lipase production by S3St2

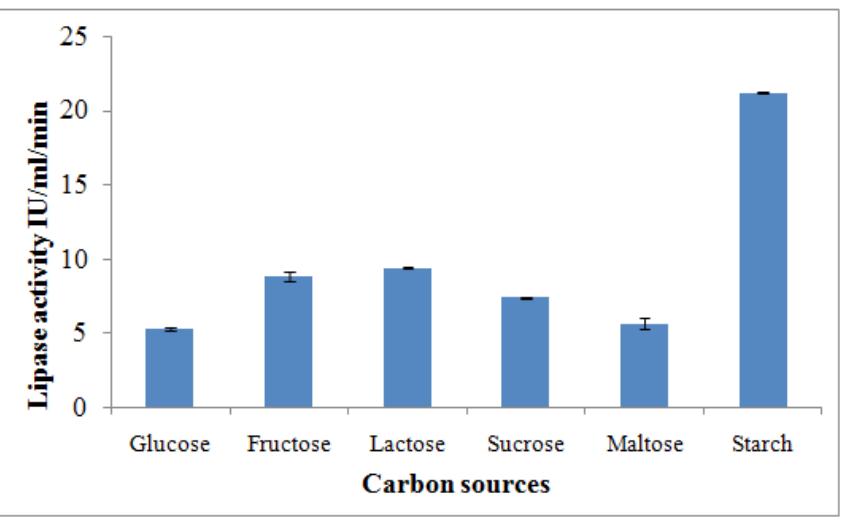

Fig 2. Effect of different carbon sources on lipase production by S3St2

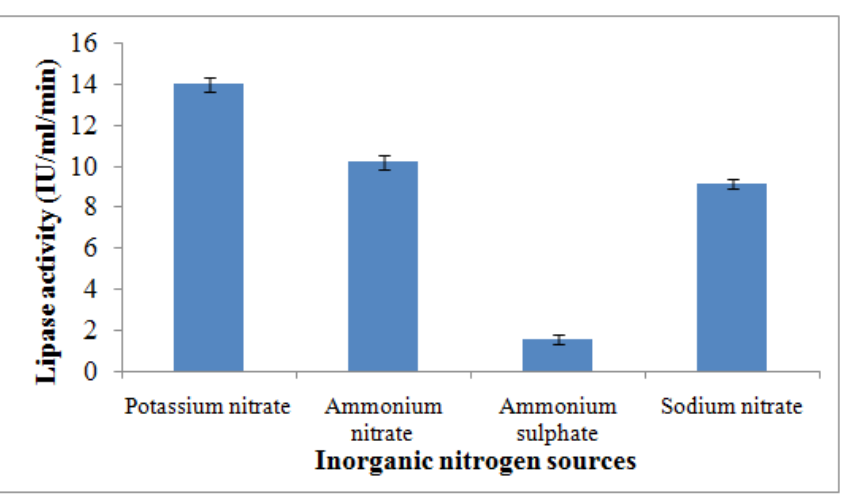

Fig 4. Effect of different inorganic nitrogen sources on lipase production by S3St2

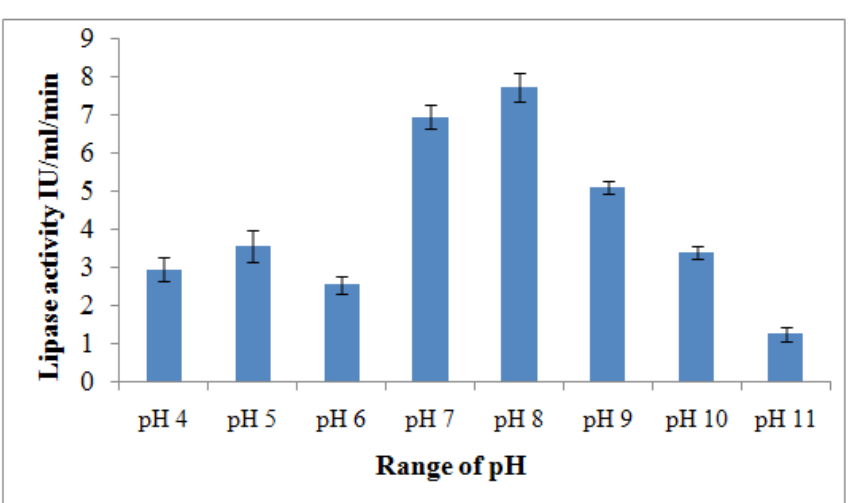

Fig 6. Effect of different pH on lipase production by S3St2

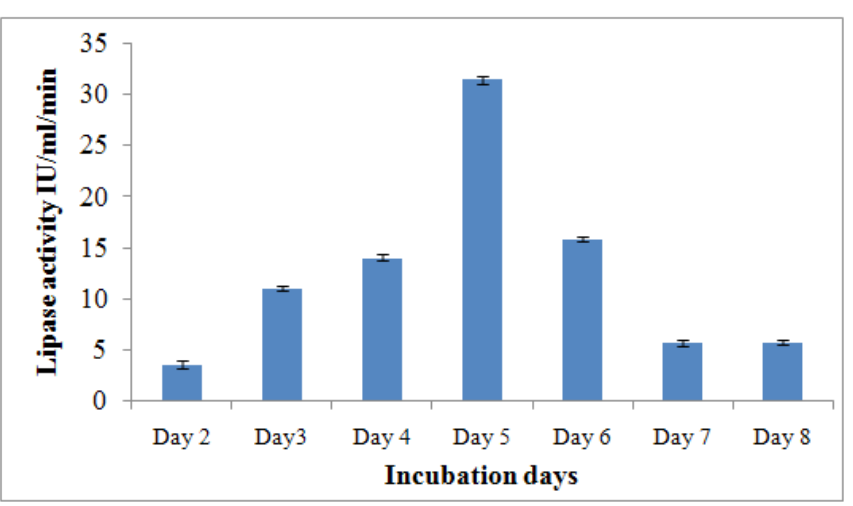

Fig 8. Effect of different incubation days on lipase production by S3St2 


\section{Determination of dry weight of fungal cell pellets}

After incubation flasks were filtered and cell pellets free supernatant was recovered from production media and it was used to check lipase activity and protein content. After filtration cell pellets were collected in glass petri plate and kept at $80^{\circ} \mathrm{C}$ to dry. The dry weight of fungal cell pellets was observed.

\section{Results}

\section{Effect of carbon sources on lipase production}

Among the different carbon sources tested, starch exhibited maximum growth and lipase production than rest of sources (Table 1). The lipase activity $(21.25 \pm 0.70 \mathrm{IU} / \mathrm{ml} / \mathrm{min})$ and specific activity $(1.47 \pm 0.06 \mathrm{U} / \mathrm{mg})$ was higher in starch carbon source followed by lactose, fructose, sucrose, maltose and glucose. Starch is a kind of polysaccharide supported lipase production by fungus, therefore, used in further optimization studies. Very few reports are available where starch was found an efficient carbon source for lipase production. The dry weight of cell pellets in presence of starch was $0.232 \mathrm{~g}$ lower than other carbon sources depicts more growth does not reflect more production of lipase. Lipase activity was lower in presence of glucose. It was probably due to that glucose was not efficiently used by fungus for growth (Fig 2).

\section{Effect of lipidic sources on lipase production}

Five different media containing amla oil, mustard oil, coconut oil, almond oil and olive oil lipidic sources were tested in order to optimize the lipase production. Among the various lipidic sources tested highest lipase activity $(13.93 \pm 0.38 \mathrm{IU} / \mathrm{ml} / \mathrm{min})$ and specific activity $(0.85 \pm 0.02 \mathrm{U} / \mathrm{mg})$ was observed with mustard oil followed by coconut oil, almond oil, amla oil and olive oil (Table 1). Mustard oil supported the growth of fungus, hence used for further optimization of culture conditions (Fig 3). Dry weight of cell pellets was higher $(0.298 \mathrm{~g})$ in presence of mustard oil lipidic source than dry weight in presence of other lipidic sources.

\section{Effect of inorganic nitrogen sources on lipase production}

Table 1 represents that among the various inorganic nitrogen sources, potassium nitrate exhibited highest lipase activity $(14.04 \pm 0.87$ $\mathrm{IU} / \mathrm{ml} / \mathrm{min})$ and specific activity $(0.95 \pm 0.10 \mathrm{U} / \mathrm{mg})$ followed by ammonium nitrate, sodium nitrate and ammonium sulphate. Potassium nitrate was the best inorganic nitrogen source for lipase production (Fig 4) and is used in further studies. Ammonium sulphate was found to be less effective and it declined lipase activity. Ammonium nitrate and sodium nitrate also supported a desirable level of lipase production. Dry weight of fungal cell pellets was higher $(0.578 \mathrm{~g})$ in presence of sodium nitrate than dry weight in presence of other inorganic nitrogen sources.

\section{Effect of organic nitrogen sources on lipase production}

Table 1 represents that among the various organic nitrogen sources, malt extract exhibited highest lipase activity $(15.29 \pm 0.96 \mathrm{IU} / \mathrm{ml} / \mathrm{min})$ and specific activity $(1.19 \pm 0.02 \mathrm{U} / \mathrm{mg})$ followed by tryptone, yeast extract, urea extract, peptone and beef extract. Malt extract was found optimum source of nitrogen for the lipase production (Fig 5) and was used for further studies. More growth of cell pellets (0.467 g) was observed in malt extract than other organic nitrogen sources. Beef extract and urea did not support the growth of fungus.

\section{Effect of $\mathbf{p H}$ on lipase production}

Lipase production was maximum at $\mathrm{pH} 8$ indicating the alkalophilic nature of the fungal isolate (Table 1). Lipase production under alkaline condition is desirable since this is the most common condition in industrial applications. Fig 6 represents the maximum lipase activity $(7.74 \pm 0.42 \mathrm{IU} / \mathrm{ml} / \mathrm{min})$ and specific activity $(1.90 \pm 0.27 \mathrm{U} / \mathrm{mg})$ at day 5 of incubation when $\mathrm{pH}$ of fermentation broth was adjusted to 8.0 and is used in further studies. Lipase activity was declined when the $\mathrm{pH}$ of production medium was further increased to pH 9.0 and 10.0. The activity and cell pellets dry weight was lower in acidic $\mathrm{pH}$ range (4.0-5.0) than in alkaline $\mathrm{pH}$ range (8.0-9.0), indicating the alkalophillic environment promotes the growth of the fungus and accumulation of lipase. The present results suggest that lipase production is affected by $\mathrm{pH}$ fluctuations. The order of lipase activity was $\mathrm{pH} 8>$ pH $7>\mathrm{pH} 9>\mathrm{pH} 5>\mathrm{pH} 10>\mathrm{pH} 4>\mathrm{pH} 6>\mathrm{pH} 11$. At $\mathrm{pH} 10$ highest dry weight (1.589 g) of cell pellets was observed but activity was less than at $\mathrm{pH} 8$.

\section{Effect of temperature on lipase production}

Table 1 represent that highest lipase activity $(27.92 \pm 0.87 \mathrm{IU} / \mathrm{ml} / \mathrm{min})$ and specific activity $(2.65 \pm 0.06 \mathrm{U} / \mathrm{mg})$ was obtained at $28^{\circ} \mathrm{C}$ as compared to lipase activity $(8.82 \pm 0.27 \mathrm{IU} / \mathrm{ml} / \mathrm{min})$ and specific activity $(1.83 \pm 0.11 \mathrm{U} / \mathrm{mg})$ at $37^{\circ} \mathrm{C}$. This indicates that fungus is capable of synthesizing high amount of lipase at $28^{\circ} \mathrm{C}$. Dry weight of cell pellets was less $(0.543 \mathrm{~g})$ at $37^{\circ} \mathrm{C}$, indicating that $37^{\circ} \mathrm{C}$ is not optimum temperature for growth of fungus (Fig 7). More weight of cell pellets ( $0.984 \mathrm{~g}$ ) was observed at $28^{\circ} \mathrm{C}$ than $37^{\circ} \mathrm{C}$.

\section{Effect of incubation time on lipase production}

Lipase production and growth of S3St2 were determined by growing the fungus in medium with $\mathrm{pH}$ 8.0. The lipase activity gradually increases from the $2^{\text {nd }}$ day of incubation to $5^{\text {th }}$ day of incubation. Maximum lipase activity $(31.51 \pm 0.21 \mathrm{IU} / \mathrm{ml} / \mathrm{min})$ and specific activity $(3.91 \pm 0.03 \mathrm{U} / \mathrm{mg})$ was obtained at $5^{\text {th }}$ day of incubation (Table 1). The production of lipase starts to decline from $6^{\text {th }}$ day till $8^{\text {th }}$ day (Fig 8). At $5^{\text {th }}$ day of incubation, dry weight of fungal cell 
pellets was higher $(0.694 \mathrm{~g})$ than dry weight of cell pellets collected from other days of incubation. The present results indicate that lipase production was associated with the growth phase.

\section{Discussion}

Similar to present result, maximum growth of fungus and production of lipase was reported in starch containing media and stated starch as an important component of medium (19). Maximum production of lipase $(21.25 \pm 0.70 \mathrm{IU} / \mathrm{ml} / \mathrm{min})$ with soluble starch as a carbon source among all seven sources (27).

Similar to present study, the highest lipase (1.3 U/ml) production was observed when mustard oil cake was used (28). Among different tested lipidic carbon sources as a substrate the highest lipase activity was reported with mustard oil lipidic source (29). Different lipidic sources were tested (linseed, soyabean, amla, mustard, coconut, olive, sunflower, til, ricinus). Among all these, linseed exhibited maximum lipase activity $(17.3 \mathrm{U} / \mathrm{ml})$. Soyabean, coconut and amla oil supported the growth of fungus (30). The highest lipase activity $(12.1 \mathrm{U} / \mathrm{ml})$ was observed with coconut oil $(1 \% \mathrm{v} / \mathrm{v})$ as a substrate (21).

The maximum lipolytic activity was demonstrated using potassium nitrate as a substrate and considered it for formulation of production media. It was stated that lipase production increased with inorganic nitrogen sources in fermentation broth. Concentration of potassium nitrate and ammonium sulphate were remained constant (24). Lipase activity was optimum with yeast extract as organic nitrogen source (31).

Similar to present result, the maximum lipase activity was also demonstrated at $\mathrm{pH} 8$ i.e. therefore alkali condition was further used for industrial production of lipase (20). In agreement with present results, highest lipase production from fungus was observed at pH $8(26,32)$. The optimum lipase production was reported from Fusarium sp. when $\mathrm{pH}$ of fermentation broth was adjusted in acidic range pH 2.5 (33). Moderate lipase production was at $\mathrm{pH}$ 5.0-6.0, while lipase activity was declined in alkaline $\mathrm{pH}$ above 8.0. An optimum $\mathrm{pH}$ of 7.0 was reported for Aspergillus sp. and for Penicillium sp.

Similar to present findings, maximum lipase activity $(19.2 \mathrm{U} / \mathrm{ml})$ was obtained by Aspergillus terreus at $30^{\circ} \mathrm{C}(34)$. The highest lipase activity (3.5 $\mathrm{U} / \mathrm{ml}$ ) was reported at $30^{\circ} \mathrm{C}$ from Trichoderma reesei (35). An optimum temperature of $30^{\circ} \mathrm{C}$ was reported for lipase production from Aspergillus heteromorphus (25).

Similar to present findings, the highest lipase activity was obtained from Fusarium sp. after $72 \mathrm{~h}$ of incubation (26). An optimum lipase activity was demonstrated from Penicillium sp after 7 days of incubation. An optimum incubation period of 96 $\mathrm{h}$ was reported for Aspergillus sp. and Aspergillus carbonarius. Lipase production was highest from Fusarium sp. after $120 \mathrm{~h}$ of incubation (33).

\section{Conclusion}

Growth of the fungus and lipase production is affected by culture conditions and type of nutrients, therefore lipase activity can be increased by providing optimum culture conditions to the growing fungus. From the present study it is apparent that the fungal cell pellets growth and consequent lipase production was increased with the change of culture conditions and nutrient type. Among the carbon sources, starch \& mustard oil and among the nitrogen sources, potassium nitrate \& malt extract were found suitable for optimum lipase production by natural lipolytic fungl isolate S3St2 under SmF. The composition of optimized media $(\mathrm{g} / 100 \mathrm{ml})$ is $0.5 \mathrm{~g}$ of starch, $1 \mathrm{ml}$ of olive oil, $0.1 \mathrm{~g}$ of potassium nitrate, $4 \mathrm{~g}$ of malt extract with $\mathrm{pH} 8$ at 5 days of incubation. Further, the optimized media can be used for optimum lipase production.

\section{Acknowledgments}

We would like warmly to thank Vice-Chancellor, Banasthali Vidyapith for providing excellent research facilities.

\section{Authors' contribution}

Experimental work was carried out by Shreya. AKS provided the protocols for experiments and written up the manuscript. VS and JS designed the experiments, analyzed the collected data and justified the results through discussion.

\section{Competing interests}

The authors declare that they have no competing interests.

\section{References}

1 Svendsen A. Review: Lipase protein engineering Biochimica et Biophysica Acta. 2000; 1543 (2): 223-238. https://doi.org/10.1016/S0167-4838(00)00239-9

2 Jaeger KE, Eggert T. Lipases for biotechnology. Current Opinion in Biotechnology. 2002; 13(4): 390-397.

3 Goao XG, Cao SG, Zhang KC. Production, properties and application to nonaqueous enzymatic catalysis on lipase from a newly isolated Pseudomonas strain. Enzyme and Microbial Technology. 2000; 27(1-2): 74-82. https://doi.org/10.1016/S0141-0229(00)00191-5

4 Dalmou E, Montesinos JL, Lotti M, Casas C. Effect of different carbon sources on lipase production by Candida rugosa. Enzyme and Microbial Technology. 2000; 26 (9-10): 657-663. https://doi.org/10.1016/S01410229(00)00156-3

5 Cardenas F, Alvarez E, de Castro- Alvarez MS, SanchezMontero JM, Valmaseda M, Elson S, Sinisterra JV. Screening and catalytic activity in organic synthesis of novel fungal and yeast lipases. Journal of Molecular 
Catalysis B: Enzymatic. 2001; 14: 111-123. https://doi.org/10.1016/S1381-1177(00)00244-7

6 Thakur S. Lipases, its sources, properties and applications: A review, International Journal of Scientific and Engineering Research. 2012; 3(7): 1-29.

7 Haq IU, Ali S, Saleem A, Javed MM. Mutagenesis of Bacillus licheniformis through ethyl methyl sulphonate for alpha amylase production. Pakistan Journal of Botany. 2009; 41(3): 1489-1498.

8 Iftikhar T, Niaz M, Zia MA, Haq IU. Production of extracellular lipases by Rhizopus oligosporus in a stirred fermentor. Brazilian Journal of Microbiology. 2010; 41: 1124-1132. 83822010000400034

9 Iftikhar T, Niaz M, Abbas SQ, Zia MA, Ashraf I, Lee KJ, Haq IU. Mutation induced enhanced biosynthesis of lipases by Rhizopus oligosporus var. microsporus. Pakistan Journal of Botany. 2010; 42(2): 1235-1249.

10 Sarada S, Sreekanth B, Kant S, Banarjee R, Bhattacharya BC. Production and optimization of microbial lipase. Bioprocess Engineering. 1998; 19(1): 29-32.

11 Iftikar T, Haq IU, Javed MM. Optimization of culture conditions for the production of lipase by submerged culture of Rhizopus oligosporus Tuv-31, Pakistan Journal of Botany. 2003; 35: 519-525.

12 Matselis E, Roussis IG. Influence of culture conditions and hydrogen peroxide on growth and extracellular enzyme production by Pseudomonas UICD31. Food Science and Technology. 1992; 25(5): 433-437.

13 Makhzoum A, Knapp JS, Owusu RK. Factors affecting growth and extracellular lipase production by Pseudomonas fluorescens 2D. Food Microbiology. 1995; 12(4): 277-290. $\quad$ https://doi.org/10.1016/S07400020(95)80108-1

14 Ghosh PK, Saxena RK, Gupta R, Yadav RP, Davidson S. Microbial Lipases: Production and applications. Science Progress. 1996; 79(2): 119-157.

15 Elibol M, Ozer D. Influence of oxygen transfer on lipase production by Rhizopus arrhizus. Process Biochemistry. 2001; 36(4): 325-329. https://doi.org/10.1016/S0032 9592(00)00226-0

16 Shukla BN, Desai PV. Isolation, Characterization and Optimization of Lipase Producing Pseudomonas spp. from Oil Contaminated Sites. International Journal of Current Microbiology and Applied Sciences. 2016; 5(5): 902-909. http://dx.doi.org/10.20546/ijcmas.2016.505.093

17 Wadia T, Jain SK. Isolation, Screening and identification of Lipase Producing Fungi from Oil Contaminated Soil of Shani Mandir Ujjain. International Journal of Current Microbiology and Applied Sciences. 2017; 6(7): 18721878. https://doi.org/10.20546/ijcmas.2017.607.223

18 Colla LM, Primaz AL, Benedetti S, Loss RA, Lima MD, Reinehr CO, Bertolin TE, Costa JA. Selection of Lipase Producing Microorganisms through Submerged Fermentation. Zeitschrift fur Naturforschung C. 2010; 65(7-8): 483-488. https://doi.org/10.1515/znc-2010-7-811.

19 Singh C, Parmar RS, Jadon P, Kumar A. Optimization of Cultural Conditions for Production of Antifungal Bioactive Metabolites by Streptomyces spp. Isolated from Soil. International Journal of Current Microbiology and

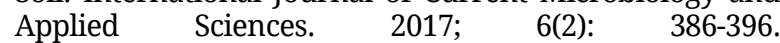
http://dx.doi.org/10.20546/ijcmas.2017.602.043

20 Kapoor A, Sharma S, Prakash S. Optimization of Culture Conditions for the Production of Lipase from Gliomastix indicus and its Enzymatic Properties. Dynamic Biochemistry, Process Biotechnology and Molecular Biology. 2012; 6(1): 118-122.

21 Joshi GK, Kumar S, Tripathi BN, Sharma V. Production of alkaline lipase by Corynebacterium paurometabolum
MTCC6841 isolated from Lake Naukuchiatal, Uttaranchal State, India. Current Microbiology. 2006; 52(5): 354-358. https://doi.org/10.1007/s00284-005-0224-6

22 Lowry OH, Rosenbrough NJ, Farr AL, Randall A. Protein measurement with the folin phenol reagent. Journal of Biological Chemistry. 1951; 193(1): 265-275.

23 Golani M, Hajela K, Pandey GP. Screening, Identification, Characterization and Production of Bacterial Lipase from Oil Spilled Soil. International Journal of Current Microbiology and Applied Sciences 2013; 5(3): 745-763. http://dx.doi.org/10.20546/ijcmas.2016.503.08

24 Valéria MG, Nadia K, Sarquis MIM, Mitchell DA, Luiz PR, Fontana JD. Effect of Nitrogen and Carbon Sources on Lipase Production by Penicillium aurantiogriseum. Food Technology Biotechnology. 2003; 41(2): 105-110.

25 Sneha PM, Parimala T, Rao CSVR, Satish BR. Effect of various sources and parameters on the production of an extracellular lipase from Aspergillus heteromorphus and optimization using response surface methodology. Journal of Chemical, Biological and Physical Sciences. 2012; 2(1): 212-222.

26 Maia MDMD, Morais MMCD, Morais MAD, Melo EHM, Filho JLDL. Production of extracellular lipase by the phytopathogenic fungus Fusarium solani FSI, Revista de Microbiologia. 1999; 30: 304-309.

27 Fan Y, Shang L, Qian J. Screening, identifying and medium optimization of a lipase producing filamentous fungus from soil for high chiral resolution of 1phenylethanol. African Journal of Microbiology Research. 2003; 7(33): 4235-4243.

28 Bokhari DN, Gohar UF, Hussain Z. Optimization Studies of Lipase Production from Locally isolated Bacillus sp. Biologia (Pakistan). 2013; 59(2): 259-265.

29 Sethi BK, Rout JR, Das R, Nanda PK, Sahoo SL. Lipase production by Aspergillus terreus using mustard seed oil cake as a carbon source. Annals of Microbiology. 2013; 63(1): 241-252. DOI https://doi.org/10.1007/s13213-0120467-y

30 Savitha J, Srividya S, Jagat R, Payal P, Priyanki S, Rashmi GW, Roshini KT, Shantala YM. Identification of potential fungal strains for the production of inducible, extracellular and alkalophilic lipase. African Journal of Biotechnology. 2007; 6(5): 564-568

31 Golani M, Hajela K, Pandey, GP. Screening, Identification, Characterization and Production of Bacterial Lipase from Oil Spilled Soil. International Journal of Current Microbiology and Applied Sciences. 2016; 5(3): 745-763. http://dx.doi.org/10.20546/ijcmas.2016.503.08

32 Supakdamrongkul P, Bhumiratana A, Wiwat, C. Optimization of extracellular lipase production from the biocontrol fungus Nomuraea rileyi. Biocontrol Science Technology. 2010; 20: 595-604 https://doi.org/10.1080/09583151003661177.

33 Sopuruchukwu IF, Nididi EM, Okerentugba PO. Optimization of Process Parameters for the Production of Lipase in Submerged Batch Fermentation by Fusarium sp. Journal of Pharmaceutical Biological Science. 2015; 10:70-78. https://doi.org/10.9790/300810237078

34 Rani C, Panneerselvam A. Influence of environmental and nutritional parameters on lipase production. Journal of Agricultural and Biological Sciences. 2009; 4(5): 39-43.

35 Rajesh EM, Arthe R, Rajendran R, Balakumar C, Pradeepa $\mathrm{N}$, Anitha S. Investigation of lipase production by Trichoderma reesei and optimization of production parameters. Electronic Journal of Environmental, Agricultural and Food Chemistry. 2010; 9(7): 1177-1189. 